CURRENT

Jurnal Kajian Akuntansi dan Bisnis Terkini

https://current.ejournal.unri.ac.id

\title{
PENGARUH CORPORATE GOVERNANCE DAN AUDIT TENURE TERHADAP AUDIT REPORT LAG PADA PERUSAHAAN LQ45
}

\author{
Joshua Sanders Gunawan', Adji Suratman², Yuniza Rova ${ }^{3}$ \\ ${ }^{123}$ Program Studi Akuntansi, Sekolah Tinggi Ilmu Ekonomi, YAI, Jakarta \\ "E-mail: joshua101097.js@gmail.com
}

\begin{tabular}{l} 
Keywords \\
\hline Human Resources \\
Competencies, \\
Utilization of \\
Information \\
Technology, The \\
Application of Internal \\
Control System, The \\
Quality of Financial \\
Reports
\end{tabular}

Article Information

Received:

2020-11-20

Accepted:

2020-11-29

Available online:

2020-11-30

\begin{abstract}
This study aims to explain how Human Resources Competencies, Utilization of Information Technology and The Application of Internal Control System determine of the Quality of Financial Reports of Pekanbaru City. This study uses a quantitative method. The population in this study were 33 OPD in Pekanbaru City Government. The sample determination technique uses a purposive sampling method, where questionnaires distributed to 99 respondents were determined to the Head of Department, Head of Division/SubDivision/Financial Staff and PPTK of each OPD. The hypothesis test used in this study uses $t$-Test. The statistical test aids used in this study were the SPSS program ver. 20 for Windows and Ms. Excel 2013. The results show that the Competencies of Human Resources, Utilization of Information Technology and the Application of Internal Control System partially affected the Quality of Local Government Financial Reports.
\end{abstract}

\section{PENDAHULUAN}

Kegiatan pasar modal di lantai Bursa Efek Indonesia beberapa tahun belakangan ini berkembang cukup pesat, adapun berdampak pada meningkatnya permintaan untuk mengaudit laporan keuangan secara efisien dan efektif (Arifuddin et al, 2017). Permintaan audit atas laporan keuangan juga mengalami peningkatan seiring dengan pesatnya perkembangan perusahaan yang go public. Perusahaan go public diharuskan menyerahkan laporan keuangan yang telah diaudit oleh akuntan publik sesuai dengan Standar Akuntansi Keuangan.

Laporan keuangan disajikan oleh perusahaan harus dapat memenuhi keinginan pengguna atau pembaca laporan keuangan dan dapat digunakan sebagai dasar untuk pengambilan keputusan. Oleh karena itu laporan Keuangan yang disajikan dapat memenuhi 
karakteristik yang kualitatif. Menurut Kerangka Dasar Penyusunan dan Penyajian Laporan Keuangan (KDP2LK), agar dapat menghasilkan laporan keuangan yang berguna bagi para penggunanya maka laporan keuangan yang disusun tersebut haruslah memenuhi karekteristik kualitatif yaitu dapat di pahami, relevan, andal dan dapat diperbandingkan. Informasi akuntansi dalam laporan keuangan dikatakan relevan apabila salah satunya telah memenuhi indikator berupa ketepatan waktu (timeliness).

Salah satu karakteristik kualitatif laporan keuangan adalah ketepatan waktu pada penyampaian laporan keuangan akan mempengaruhi pengambilan keputusan. Oleh karena itu ketepatan dalam waktu penyusunan laporan keuangan merupakan hal yang sangat penting. Laporan Keuangan merupakan informasi bagi pengguna laporan keuangan untuk melihat dan menilai kondisi keuangan serta kinerja perusahaan. Laporan Tahunan Perusahaan Publik atau Laporan Tahunan Emiten di atur pada Peraturan Otoritas Jasa Keuangan (POJK) No.29/POJK.04/2016 pasal 7 ayat (1), menerangkan bahwa "Emiten atau Perusahaan Publik wajib menyampaikan Laporan Tahunan kepada Otoritas Jasa Keuangan Paling lambat pada akhir bulan keempat setelah tahun buku berakhir". Menurut penelitian Ariani \& Bawono (2018) “jangka waktu auditor mengaudit berpengaruh terhadap ketepatan waktu laporan keuangan dipublikasikan dan informasi yang terkandung didalamnya. Rentang waktu antara tanggal tutup buku perusahaan dengan tanggal dikeluarkannya opini auditor dapat diketahui lamanya waktu penyelesaian audit dalam dunia audit disebut sebagai audit report lag".

Dalam menentukan kualitas laporan keuangan faktor ketepatan waktu adalah hal yang sangat penting, namun masih terdapat kasus keterlambatan dalam menyampaikan laporan keuangan perusahaan yang terdaftar di BEI. Berdasarkan data BEI Mei 2019, ditemukan 714 perusahaan yang telah terdaftar di BEI atau Bursa Efek Indonesia dimana terdapat perusahaan yang wajib memberikan laporan keuangan yang telah di audit untuk periode 2018 sebanyak 692 perusahaan. Namun masih ditemukan perusahaan yang mangkir dari kewajiban memberikan dan mempublikasikan laporan keuangan sehingga sesuai aturan pasar modal. Sebanyak 24 perusahaan yang terdaftar di Bursa Efek Indonesia (BEI) akan mendapatkan sanksi dari otoritas bursa karena belum menyampaikan laporan keuangan. BEI telah menyampaikan Peringatan Tertulis II dan juga yang dikenakan sanksi denda sebesar Rp. 50 juta atas keterlambatan penyampaian tersebut (Ayuningtyas, 2019).

Terdapat beberapa faktor yang mempengaruhi audit report lag diantaranya adalah dari sisi corporate governance dan ukuran perusahaan. Jika suatu perusahaan memiliki tata kelola perusahaan yang baik maka hal ini akan lebih memudahkan pekerjaan auditor dalam hal penilaian risiko pengendalian serta dalam hal perencanaan auditnya sehingga akan 
memperpendek audit report lag.

Good Corporate Governance (GCG) adalah pencapaian kesepadaan antara kekuatan serta kewenangan perusahaan dalam membagikan pertanggung jawabannya kepada para shareholder khususnya sebagai prinsip dalam mengarahkan dan mengendalikan perusahaan. Keadaan ini tentu saja dimaksudkan untuk mengatur kewenangan Direktur, manajer, pemegang saham dan pihak lain yang berkaitan dengan keberlanjutan perusahaan di lingkungan tertentu. Asian Development Bank (ADB) menjelaskan bahwa "GCG mengandung empat nilai utama yaitu: accountability, transparency, predictability dan participation". Pengertian sama juga di jelaskan dari Finance Comitte on Corporate Governance Malaysia.

Dewan komisaris (Board of commissioner) adalah suatu sistem pengendalian intern tertinggi yang bertanggung jawab untuk mengawasi kegiatan manajemen puncak (Kusumah \& Manurung, 2017). Dewan Komisaris menurut penelitian Kusumah \& Manurung (2017) "berfungsi untuk mengawasi pengelolaan perusahaan yang dilaksanakan oleh manajemen (dewan direksi) dan bertanggung jawab untuk menentukan apakah manajemen telah memenuhi tanggung jawab mereka dalam mengembangkan dan menyelenggarakan pengendalian internal perusahaan". Menurut penelitian yang dilakukan oleh Kusumah \& Manurung (2017), menyatakan bahwa "semakin besar jumlah anggota dewan komisaris, maka akan semakin mudah untuk mengendalikan board of director (CEO) dan pengawasan yang dilakukan akan semakin efektif. Jika dikaitkan dengan pengungkapan laproan keuangan perusahaan, tekanan terhadap manajemen juga akan semakin besar untuk mengungkapkannya”.

Internal auditor menjelaskan pemeriksaan, pengawasan dan penilaian akan kinerja, resiko dan tata kelola (governance) pada perusahaan publik maupun privat untuk menyampaikan suatu pencapaian tujuan langsung organisasi, yang merupakan penyediaan jasa-jasa dari suatu fungsi penilai independen. Maka dari itu auditor tidak lagi memerlukan waktu yang lama dalam melaksankan pengujian laporan keuangan pengauditan dan hal ini dapat mengurangi terjadinya penundaan panyajian laporan keuangan atau audit delay pada perusahaan tersebut (Mahendra dan Widhiyani, 2017). Nanda (2014) mengutarakan bahwa fungsi internal auditor tidak berpengaruh terhadap audit delay.

Menurut penelitian Giri (2010) "Pemenuhan standar profesi dengan cepat dan tepat sehingga dapat mempersingkat waktu penyelesaian audit ditentukan oleh pemahaman yang tinggi atas karakteristik bisnis dan operasional perusahaan. Audit tenure adalah sebagai jumlah tahun suatu KAP atau seorang auditor mengaudit suatu perusahaan. Tenure yang panjang dari suatu KAP akan menambah pengetahuan KAP dan atau auditor mengenai bisnis 
perusahaan sehingga dapat merancang program audit yang lebih baik".

Adapun penelitian terdahulu mengenai corporate governance dan audit tenure beserta pengaruhnya terhadap audit report lag telah banyak dilakukan dan hasilnya bervariasi. Penelitian Kusumah dan Manurung (2017) meneliti pentingnya Good Corporate Governance Bagi Audit Report Lag menyimpulkan rapat komite audit, ukuran dewan komisaris dan KAP Big 4 tidak berpengaruh terhadap audit report lag. Sedangkan dewan komisaris independen berpengaruh negatif terhadap audit report lag. Kusumah dan Manurung (2017) juga meneliti Pengaruh Kualitas Audit, Masa Audit untuk Laporan Audit Lag dengan Industri Khusus Auditor sebagai Variabel Moderating menyimpulkan audit tenure dan kualitas audit memiliki pengaruh terhadap keterlambatan laporan audit. Penelitian Butarbutar dan Hadiprajitno (2017) meneliti faktor-faktor yang berpengaruh terhadap audit report lag menyimpulkan ukuran dewan komisaris memiliki pengaruh signifikan terhadap audit report lag, sedangkan komite audit tidak memiliki pengaruh signifikan terhadap audit report lag. Selanjutnya pada penelitian Sari dan Ghozali (2014) yang mengungkapkan Komite Audit tidak memiliki pengaruh signifikan terhadap audit report lag.

Berbagai penelitian di atas dilakukan pada berbagai macam perusahaan, diantaranya perusahaan yang terdaftar di Bursa Efek Indonesia atau disingkat BEI yaitu perusahaan non keuangan menurut sektornya yaitu industry manufaktur, sedangkan dalam penelitian ini, penulis melakuakan penelitian pada perusahaan-perusahaan yang masuk dalam indeks LQ45 yang terdaftar di Bursa Efek Indonesia dengan periode penelitian dari tahun 2016 sampai dengan 2018.

Berdasarkan pemaparan di atas, maka dilakukan penelitian dengan tujuan untuk mengetahui adanya pengaruh Dewan Komisaris, Komite Audit, Internal Audit dan Audit Tenure terhadap Audit Report Lag secara parsial dan simultan.

\section{PENGEMBANGAN HIPOTESIS}

\section{Pengaruh Dewan Komisaris Terhadap Audit Report Lag}

Teori agensi menyatakan bahwa pihak pemilik (principal) terdorong terhadap transparansi, tidak adanya kelalaian, dan ketepatan waktu yang dilakukan oleh manajer (agent). Pada penelitan Butarbutar dan Hadiprajitno (2017) menyatakan bahwa, "semakin banyak jumlah dewan komisaris maka semakin baik dalam melaksanakan tanggung jawabnya sehingga akan tercapainya arah dan tujuan perusahaan. Hal ini dikarenakan dewan komisaris bertugas dalam mengawasi seluruhan kebijakan dalam perusahaan, jalannya kepengurusan yang sesuai anggaran dasar, dan juga memberikan nasihat kepada dewan direksi sehingga 
mampu meningkatkan kinerja perusahaan yang kemudian akan meningkatkan kualitas laporan keuangan perusahaan dan juga dapat mengurangi audit report lag".

Penelitian dari Kumara (2015), Faishal \& Hadiprajitno (2015) serta Butarbutar dan Hadiprajitno (2017) menyatakan bahwa dewan komisaris berpengaruh signifikan terhadap audit report lag.

\section{$\mathrm{H}_{1}$ : Dewan komisaris berpengaruh terhadap audit report lag.}

\section{Pengaruh Komite Audit Terhadap Audit Report Lag}

Menurut penelitian Faisal dan Hadiprajitno (2015) "komite audit diharapkan dapat menyelesaikan konflik dengan manajemen dan melakukan perbaikan dalam kualitas audit secara keseluruhan. Komite audit sekarang sedang dilihat sebagai pemain utama dalam upaya untuk melaksanakan reformasi pemerintahan dan membangun kembali kepercayaan publik dalam pelaporan keuangan. Sebagai hasil dari langkah-langkah dan tanggungjawab baru, akan ada juga perubahan hubungan antara manajemen, komite audit, dan auditor eksternal".

Penelitian Naimi (2010) dan Isnania (2018) menyatakan bahwa komite audit berpengaruh signifikan terhadap audit report lag. Sedangkan penelitian Sari dan Ghozali (2014) menyatakan komite audit tidak memiliki pengaruh yang signifikan terhadap audit report lag.

\section{$\mathrm{H}_{2}$ : Komite audit berpengaruh terhadap audit report lag.}

\section{Pengaruh Audit Internal Terhadap Audit Report Lag}

Internal auditor menjelaskan pemeriksaan, pengawasan dan penilaian akan kinerja, resiko dan tata kelola (governance) pada perusahaan publik maupun privat untuk menyampaikan suatu pencapaian tujuan langsung organisasi, yang merupakan penyediaan jasa-jasa dari suatu fungsi penilai independen. Tugas langsung dari internal auditor yaitu mengacu pada penegahan tindakan kecurangan dalam semua bentuknya atau perluasan dalam setiap aktivitas yang ditelaah, independen terhadap aktivitas yang diaudit secara periodik dan membuat rekomendasi tentang perbaikan yang diperlukan dalam perusahaan. Maka dari itu auditor tidak lagi memerlukan waktu yang lama dalam memenuhi pengujian laporan keuangan pengauditan dan hal ini dapat mengurangi terjadinya penundaan panyajian laporan keuangan atau audit delay pada perusahaan tersebut (Mahendra dan Widhiyani, 2017).

Penelitian dari Sari (2016) menunjukkan internal auditor berpengaruh signifikan terhadap audit report lag, begitu juga penelitian Nanda (2014) menyatakan bahwa fungsi internal auditor tidak berpengaruh terhadap audit report lag.

\section{$\mathrm{H}_{3}$ : Audit internal berpengaruh terhadap audit report lag.}




\section{Pengaruh Audit Tenure Terhadap Audit Report Lag}

Semakin lama masa kerja sama antara KAP dengan perusahaan klien, maka semakin baik auditor dalam mengenali industri klien. Sehingga dapat menyelesaikan laporan keuangan secara tepat waktu dan juga akan memperpendek masa penyelesaikan audit (Rustiarini et al, 2013). Maka dari itu akan mewujudkan efisiensi yang akan lebih meningkat, sehingga waktu yang diperlukan dalam penanganan audit pada laporan keuangan akan semakin lebih cepat.

Penelitian dari Sisilawati, et al (2012) mengutarakan dimana audit tenure tidak berpengaruh signifikan terhadap audit report lag. Sedangkan penelitian dari Dewi (2014), Anggreni (2016), Kusumah dan Manurung (2017) menyatakan bahwa audit tenure berpengaruh signifikan terhadap audit report lag.

\section{$\mathrm{H}_{4}$ : Audit tenure berpengaruh terhadap audit report lag.}

\section{METODE PENELITIAN}

Metodologi penelitian yang digunakan peneliti adalah metode penelitian dokumentasi, yaitu berupa metode pengumpulan data sekunder melalui website Bursa Efek Indonesia yang berupa laporan keuangan. Metode jenis penelitian yang dipakai oleh peneliti adalah penelitian asosiatif. Penelitian asosiatif merupakan penelitian yang bertujuan untuk menanggapi pengaruh hubungan antara dua variabel atau lebih. Selain itu peneliti menggunakan pendekatan kuantitatif. Menurut sugiyono (2017) "pendekatan kuantitatif adalah metode penelitian yang menggunakan proses data-data yang berupa angka sebagai alat menganalisis dan melakukan kajian penelitian, terutama mengenai apa yang sudah diteliti”.

\section{Populasi dan Sampel}

Populasi pada penelitian ini ialah semua perusahaan pada LQ45 selama periode 20162018 sebanyak 45 perusahaan. Pengambilan sampel pada penelitian ini dilaksanakan dengan memanfaatkan metode purposive sampling dan 22 perusahaan yang menjadi sampel dalam penelitian ini.

\section{Tabel 1}

\section{Penentuan Sampel}

\section{Keterangan}

Perusahaan yang tercatat pada Bursa Efek Indonesia dan termasuk dalam indeks LQ-45 secara berturut-turut Selama tahun 2016-2018.

Perusahaan yang membukukan laporan keuangan secara tidak lengkap pada tahun 2016-2018.

Perusahaan yang tidak memakai mata uang rupiah pada laporan keuangan. Laporan perusahaan yang tidak menyediakan informasi yang dibutuhkan dalam penelitian.
Jumlah Perusahaan 


\section{Definini Operasional Variabel}

Pada penelitian ini terdiri dari lima variabel yang dimana satu variabel dependen dan empat variabel independen. Dalam Penelitian ini, yang termasuk variabel dependen adalah audit report lag sebagai variabel (Y), sementara itu, yang termasuk dalam variabel independen yaitu dewan komisaris $\left(\mathrm{X}_{1}\right)$, komite audit $\left(\mathrm{X}_{2}\right)$, audit internal $\left(\mathrm{X}_{3}\right)$ dan audit tenure $\left(\mathrm{X}_{4}\right)$. Pengukuran variabel dapat dilihat pada tabel 2

\section{Tabel 2}

\section{Operasional Variabel}

\begin{tabular}{|c|c|c|c|}
\hline No & Variabel & Pengukuran & Skala \\
\hline 1. & $\begin{array}{l}\text { AUDIT REPORT } \\
\text { LAG (ARL) }\end{array}$ & $\begin{array}{l}\text { Audit repot lag diukur dengan menggunakan jumlah hari } \\
\text { setelah } 31 \text { desember (laporan keuangan tahunan) sampai } \\
\text { laporan keuangan ditanda tangani oleh auditor independen. }\end{array}$ & RASIO \\
\hline 2. & $\begin{array}{l}\text { DEWAN } \\
\text { KOMISARIS } \\
\text { (DK) }\end{array}$ & $\begin{array}{l}\text { Dewan Komisaris diukur dengan jumlah seluruh anggota } \\
\text { dewan komisaris yang ada di perusahaan } \\
\text { DK = } \sum \text { Anggota DK }\end{array}$ & RASIO \\
\hline 3. & $\begin{array}{l}\text { KOMITE AUDIT } \\
\text { (KA) }\end{array}$ & $\begin{array}{l}\text { Komite Audit diukur bedasarkan jumlah seluruh anggota } \\
\text { komite audit yang ada di perusahaan } \\
\text { KA }=\sum \text { Anggota KA }\end{array}$ & RASIO \\
\hline 4. & $\begin{array}{l}\text { AUDIT } \\
\text { INTERNAL (AI) }\end{array}$ & $\begin{array}{l}\text { Audit Internal diukur bedasarkan jumlah seluruh anggota } \\
\text { Auditor Internal yang ada di perusahaan } \\
\mathrm{AI}=\sum \text { Anggota AI }\end{array}$ & RASIO \\
\hline 5. & $\begin{array}{l}\text { AUDIT TENUR } \\
\text { (AT) }\end{array}$ & $\begin{array}{l}\text { Audit Tenure diukur bedasarkan dengan jumlah tahun } \\
\text { perikatan antara Kantor Akuntan Publik dengan perusahaan }\end{array}$ & RASIO \\
\hline
\end{tabular}

\section{Teknik Analisis Data}

Penelitian ini memanfaatkan analsis data panel, yang merupakan kombinasi antara data deret lintang (cross-section) dan data deret waktu (time-series). Menurut Gujarati (2003) "untuk menggambarkan data panel secara singkat, misalkan pada data cross section, nilai dari satu variabel atau lebih dikumpulkan untuk beberapa unit sampel pada suatu waktu". Metode analisis yang digunakan dalam penelitian ini adalah analisis deskriptif kualitatif dan kuantitatif. Menurut Marzuki (2005) "Analisis deskriptif kualitatif digunakan untuk mendeskripsikan fenomena-fenomena yang berkaitan dengan permasalahan yang diteliti. Sedangkan analisis deskriptif kuantitatif digunakan untuk menganalisis informasi kuantitatif (data yang dapat diukur, diuji dan diinformasikan dalam bentuk persamaan, tabel dan sebagainya)". Tahapan analisis kuantitatif berisikan estimasi model regresi dengan menggunakan data panel, regresi persamaan linier berganda dan uji statistic

\section{HASIL PENELITIAN DAN PEMBAHASAN}

\section{Analisis Statistik Deskriptif}

Berikut tabel 3 yang menunjukkan deskriptif statistik variable: 


\section{Tabel 3}

\section{Statistik Deskriftif}

\begin{tabular}{lccccc} 
& $\mathbf{Y}$ & $\mathbf{X 1}$ & $\mathbf{X 2}$ & $\mathbf{X 3}$ & $\mathbf{X 4}$ \\
\hline Mean & 56.68 & 6.19 & 3.67 & 180.15 & 2.98 \\
Median & 56.50 & 6.00 & 3.00 & 16.500 & 3.00 \\
Maximum & 119.00 & 11.00 & 6.00 & 2657.00 & 6.00 \\
Minimum & 14.00 & 3.00 & 3.00 & 5.00 & 1.00 \\
Std. Dev. & 20.97 & 1.69 & 1.05 & 537.35 & 1.37 \\
\hline
\end{tabular}

Sumber: Hasil Olah Data dengan menggunakan E-views

Berdasarkan Tabel 3 di atas disimpulkan sebagai berikut: hasil analisis deskriptif untuk variabel dependen menunjukkan masa audit report lag paling pendek 14 hari dan paling panjang 119 hari. Rata-rata waktu mundur penyelesaian audit untuk perusahaan-perusahaan indeks LQ45 tahun 2016-2018 adalah 57 hari (dibulatkan) sejak 31 Desember atau berakhirnya tahun fiskal.

Rata-rata dewan komisaris menunjukkan sebesar 6,197, yang artinya bahwa terdapat rata-rata sekitar 6 orang sampel dari perusahaan sebagai jumlah komisaris. Jumlah komisaris yang paling sedikit sebanyak 3 orang dan jumlah komisaris yang paling banyak sebanyak 11 orang. Berdasarkan data tersebut dapat ditarik kesimpulan bahwa perusahaan dengan dewan komisaris yang besar lebih baik ketika melakukan pengawasan dari pada perusahaan dengan dewan komisaris yang kecil.

Pada Tabel 3 memperlihatkan bahwa rata-rata nilai komite audit yang paling sedikit adalah 3 orang dan yang paling banyak adalah 6 orang. Komite audit bernilai rata-rata adalah 3,67. Jadi rata-rata jumlah komite audit dalam perusahaan sampel sebanyak 4 orang. Rata-rata jumlah komite audit perusahaan sampel telah sesuai dengan Pembentukan dan Pedoman Pelaksanaan Kerja Komite Audit yang terdapat pada Keputusan Ketua BAPEPAM dan LK No KEP-643/BL/2012 yang menyatakan bahwa komite audit paling kurang terdiri dari 3 orang anggota.

Internal audit memiliki nilai terendah (minimum) sebesar 5, sedangkan nilai tertinggi (maksimum) sebesar 2657 auditor, dengan rata-rata (mean) sebesar 180,15 auditor. Berdasarkan data tersebut dapat ditarik kesimpulan bahwa perusahaan dengan audit internal yang besar lebih baik ketika melakukan pemeriksaaan dari pada perusahaan dengan audit internal yang kecil.

Nilai minimum untuk audit tenure adalah 1 dan maksimum 6. Artinya perikatan audit paling pendek 1 tahun dan perikatan paling panjang adalah 6 tahun. Perusahaan-perusahaan indeks LQ45 tahun 2016-2018 rata-rata menggunakan jasa KAP yang sama selama 3 tahun. Beberapa perusahaan melakukan pergantian 150, bisa kurang atau lebih dari 3,480 tahun dengan tingkat penyimpangan sebesar 1,556. 


\section{Uji Kesesuaian Model}

Dalam pemilihan model yang tepat, ada beberapa uji yang perlu dilaksanakan. Pertama, menggunakan uji signifikan fixed effect uji $\mathrm{F}$ atau chow-test. Chow-test atau likelihood ratio test adalah pengujian F Statistic untuk memilih apakah model yang digunakan Common atau fixed effect. Kedua, Lagrange Multiplier (LM) adalah uji untuk mengetahui apakah Random Effect Model (REM) atau Pooled Least Square (PLS). Sedangkan ketiga, uji Hausman adalah uji untuk memilih model fixed effect atau random effect (Baltagi, 2005). Berikut tabel hasil uji kesesuaian model regresi:

\section{Tabel 4}

Kesimpulan Uji Kesesuaian Model Regresi

\begin{tabular}{ccc}
\hline Uji & \multicolumn{1}{c}{ Model } & Model Regresi yang Sesuai \\
\hline Chow & - Common Effect Model & Fixed Effect Model \\
& - Fixed Effect Model & Random Effect Model \\
Lagrange Multiplier & - Common Effect Model & \\
& - Random Effect Model & Random Effect Model \\
Hausman & - Random Effect Model & \\
\hline
\end{tabular}

Berdasarkan uji chow model panel yang dipilih adalah fixed effect model, dan dilanjutkan dengan uji lagrange multiplier model yang sesuai adalah model random effect. Karena pada uji lagrange multiplier model yang sesuai adalah random effect maka dilanjutkan dengan uji Hausman untuk menentukan apakah model yang sesuai yaitu random effect atau fixed effect. Setelah uji Hausman model regresi yang sesuai adalah random effect model. Hal ini berarti model random effect model yang akan dipilih menjadi model regresi dalam data panel.

\section{Uji Asumsi Klasik}

\section{Uji Multikolinearitas}

\section{Tabel 5}

\section{Hasil Uji Multikolinearitas}

\begin{tabular}{ccccc}
\hline & $\mathbf{X 1}$ & $\mathbf{X 2}$ & $\mathbf{X 3}$ & $\mathbf{X 4}$ \\
\hline $\mathrm{X} 1$ & 1.000000 & 0.535530 & 0.588089 & -0.005303 \\
X2 & 0.535530 & 1.000000 & 0.480587 & 0.017630 \\
X3 & 0.588089 & 0.480587 & 1.000000 & 0.078430 \\
X4 & -0.005303 & 0.017630 & 0.078430 & 1.000000 \\
\hline
\end{tabular}

Sumber: Hasil olah data dengan menggunakan E-views

Berdasarkan tabel 5 bahwa tidak terdapat variabel independen yang memiliki nilai lebih dari 0,8, sehingga dapat disimpulkan tidak terjadi multikolinearitas dalam model regresi. 


\section{Hasil Uji Heteroskedastisitas}

\section{Tabel 6}

\section{Hasil Uji Heteroskedastisitas}

\begin{tabular}{llll}
\hline \multicolumn{4}{c}{ Heteroskedasticity Test: Glejser } \\
\hline F-statistic & 1.819440 & Prob. F(4,61) & 0.1366 \\
Obs*R-squared & 7.034972 & Prob. Chi-Square(4) & 0.1341 \\
Scaled explained SS & 7.176912 & Prob. Chi-Square(4) & 0.1268 \\
Sumber: Olah data dengan & menggunakan E-views &
\end{tabular}

Berdasarkan dari hasil tabel diatas dimana nilai p value yang ditetapkan dengan nilai Prob.chi square (2) pada $O b s * R$-Squared yaitu sebesar 0,1341. Karena nilai $p$ value $0,1341>$ 0,05 maka $\mathrm{H}_{0}$ diterima atau yang berarti model regresi bersifat homoskedastisitas atau dengan kata lain tidak terjadi heteroskedastisitas.

\section{Analisis Regresi Linear Berganda}

\section{Hasil Pengujian Hipotesis Pertama $\left(\mathrm{H}_{1}\right)$}

Nilai koefisien sebesar $-62,38851$ yang menandakan bahwa dewan komisaris $\left(\mathrm{X}_{1}\right)$ mempunyai pengaruh negatif terhadap audit report lag (Y). Nilai siginifikansi sebesar 0,3209 $>0,05$ yang disimpulkan dewan komisaris $\left(\mathrm{X}_{1}\right)$ tidak berpengaruh siginifikan terhadap audit report lag (Y). 


\section{Tabel 7}

\section{Hasil Analisis Regresi Linear Berganda}

Method: Panel EGLS (Cross-section random effects)

Sample: 20162018

Periods included: 3

Cross-sections included: 22

Total panel (balanced) observations: 66

\begin{tabular}{crrrr}
\hline \hline Variable & Coefficient & Std. Error & t-Statistic & Prob. \\
\hline \hline C & 62.38851 & 16.32128 & 3.822526 & 0.0003 \\
X1 & -2.320726 & 2.318930 & -1.000774 & 0.3209 \\
X2 & 1.389691 & 3.321811 & 0.418354 & 0.6772 \\
X3 & -0.015272 & 0.007600 & -2.009324 & 0.0489 \\
X4 & 2.120873 & 1.677405 & 1.264378 & 0.2109 \\
\hline \hline
\end{tabular}

\begin{tabular}{lrr}
\hline \hline & Effects Specification & \\
& S.D. & Rho \\
\hline \hline Cross-section random & 14.06562 & 0.5456 \\
Idiosyncratic random & 12.83726 & 0.4544 \\
\hline \hline
\end{tabular}

Weighted Statistics

\begin{tabular}{llll}
\hline \hline R-squared & 0.161355 & Mean dependent var & 26.42346 \\
Adjusted R-squared & 0.106362 & S.D. dependent var & 13.29510 \\
S.E. of regression & 12.56819 & Sum squared resid & 9635.517 \\
F-statistic & 2.934088 & Durbin-Watson stat & 1.751651 \\
Prob(F-statistic) & 0.027641 & & \\
\hline \hline & \multicolumn{2}{|c|}{ Unweighted Statistics } & 56.68182 \\
\hline \hline \multirow{2}{*}{ R-squared } & 0.297322 & Mean dependent var & 0.840073 \\
Sum squared resid & 20091.20 & Durbin-Watson stat & \\
\hline \hline
\end{tabular}

Sumber: Olah data dengan menggunakan E-views

Berdasarkan Tabel 7 model regresi linier berganda untuk model random effect model: $Y=62,38851-2,320726 * X 1+1,389691 * X 2-0,015272 * X 3+2,120873 * X 4+[C X=R \ldots$ (1)

Dari hasil uji menunjukkan dewan komisaris tidak berpengaruh terhadap audit report lag. Hal ini tidak sesuai dengan teori agensi, yang menyatakan bahwa pihak pemilik (principal) terdorong terhadap transparansi, tidak adanya kelalaian, dan ketepatan waktu yang dilakukan oleh manajer (agent). Dengan begitu, semakin banyak dewan akan semakin banyak jumlah anggota yang akan lebih fokus terhadap masing-masing departemen dan mengurangi audit report lag. Sedangkan menurut Mark dan Li dalam Wardhani dan Raharja (2013) menyatakan bahwa dewan komisaris dengan anggota yang besar mungkin akan menyebabkan kurang munculnya partisipasi, kurang terorganisir, serta sulit dalam menemukan suatu kemufakatan. Hal ini akan dapat memperlambat penyampaian laporan auditor. Hasil penelitian ini sepaham dengan penelitian yang dilakukan oleh Kusumah dan Manurung (2017) bahwa dewan komisaris tidak berpengaruh terhadap audit report lag. 


\section{Hasil Pengujian Hipotesis Kedua $\left(\mathrm{H}_{2}\right)$}

Nilai koefisien sebesar 1,389691 yang menandakan bahwa komite audit $\left(\mathrm{X}_{2}\right)$ mempunyai pengaruh positif terhadap audit report lag (Y). Nilai siginifikansi sebesar 0,6775 > 0,05 yang disimpulkan komite audit $\left(\mathrm{X}_{2}\right)$ tidak berpengaruh siginifikan terhadap audit report lag (Y).

Hasil penelitian ini menunjukkan bahwa ukuran komite audit belum dapat menurunkan audit report lag perusahaan. Hal ini berarti bahwa pada waktu audit report lag tidak langsung terjadi pada perusahaan yang memiliki jumlah anggota komite audit yang lebih besar. Hal tersebut disebabkan tugas dan wewenang dari komite audit tidak berdampak langsung dalam prosedur audit yang dilaksanakan oleh auditor eksternal, auditor tidak akan berdampak terhadap jumlah anggota komite audit yang dimiliki oleh perusahaan (Pramaharjan dan Cahyonowati, 2015). Hasil penelitian ini sependapat dengan penelitian yang dilakukan oleh Butarbutar dan Hadiprajitno (2017) dimana komite audit tidak berpengaruh signifikan terhadap audit report lag.

\section{Hasil Pengujian Hipotesis Ketiga $\left(\mathrm{H}_{3}\right)$}

Nilai koefisien sebesar -0,015272 yang menandakan bahwa audit internal $\left(\mathrm{X}_{3}\right)$ mempunyai pengaruh negatif terhadap audit report lag (Y). Nilai siginifikansi sebesar 0,0489 $<0,05$ yang disimpulkan audit internal $\left(\mathrm{X}_{3}\right)$ berpengaruh siginifikan terhadap audit report lag (Y). Semakin besar proporsi audit internal maka akan dapat mempercepat laporan audit atau tidak terjadinya audit report lag. Hal ini menunjukan bahwa performansi perusahaan yang baik memiliki struktur audit yang baik juga, sehingga mampu menyajikan laporan keuangan perusahaan dengan baik dan juga akuntan publik yang mengaudit perusahaan dapat menyampaikan laporan keuangan secara tepat waktu.

Hasil penelitian ini tidak sepaham dengan penelitian yang dilaksanakan oleh Mahendra dan Widhiyani (2017) dimana audit internal berpengaruh signifikan terhadap audit report lag.

\section{Hasil Pengujian Hipotesis Keempat $\left(\mathrm{H}_{4}\right)$}

Nilai koefisien sebesar 2,120873 yang menandakan bahwa audit tenure $\left(\mathrm{X}_{4}\right)$ mempunyai pengaruh negatif terhadap audit report lag (Y). Nilai siginifikansi sebesar 0,2109 $>0,05$ yang disimpulkan audit tenure $\left(\mathrm{X}_{4}\right)$ tidak berpengaruh siginifikan terhadap audit report lag (Y). Hal ini memungkinkan semakin lamanya tahun perikatan KAP dengan perusahaan, maka akan terjadinya audit report lag. Menurut Bhoor \& Khamees (2016) menyatakan "bahwa lama atau tidaknya tenure KAP tidak berpengaruh terhadap audit report lag." Hal 
tersebut dapat terjadi karena apabila KAP yang menyerahkan jasa audit merupakan KAP yang sama seperti tahun sebelumnya tetapi para auditor pelaksananya berbeda maka para auditor tersebut tetap harus mempelajari kembali mengenai perusahaan sehingga tidak dapat menghasilkan ARL yang lebih singkat.

Berdasarkan teori legitimasi, perusahaan dengan audit tenure yang singkat maka akan menghasilkan ARL yang lebih panjang serta semakin panjang audit tenure maka akan menghasilkan audit report lag yang lebih pendek (Dewi \& Hadiprajitno, 2017). Hasil penelitian ini sependapat dengan penelitian yang dilaksanakan oleh Dewi dan Hadiprajitno (2017) dimana Audit tenure tidak memiliki pengaruh signifikan terhadap audit report lag.

\section{SIMPULAN}

Berdasarkan hasil penelitian maka dapat disimpulkan bahwa dewan komisaris, komite audit dan audit tenure tidak berpengaruh signifikan terhadap audit report lag. Sedangkan audit internal berpengaruh signifikan terhadap audit report lag pada perusahaan LQ 45 .

Penelitian ini memiliki keterbatasan hanya dilakukan pada perusahaan LQ 45 sebanyak 22 sampel, sehingga hasil penelitian tidak dapat digeneralisasi pada perusahaan lainnya. Oleh sebab itu, penelitian selanjutnya dapat memperluas objek penelitian lebih luas. Penelitian ini juga memiliki variabel yang terbatas yaitu hanya meneliti mekanisme good corporate governance dewan komisaris, komite audit, audit internasional dan audit report lag. Peneliti selanjutnya dapat mengembangkan penelitian dengan menggunakan variabel lain seperti spesifikasi industri, kompleksitas industri (Habib, et al 2018).

Penelitian ini memiliki kontribusi pada literatur good governance dan kualitas laporan keungan. Selain itu penelitian ini menguatkan bukti bahwa audit internal berpengaruh signifikan terhadap audit report lag pada perusahaan LQ 45 sehingga perlunya penguatan peran audit internal pada perusahaan untuk mengurangi keterlambatan penyampaian laporan keungan.

\section{REFERENSI}

Ariani, K. R., \& Bawono, A. D. (2018). Pengaruh Ukuran dan Umur Perusahaan Terhadap Audit Report Lag dengan Profitabilitas dan Solvabilitas Sebagai Variabel Moderating. Riset Akuntansi dan Keuangan Indonesia 3(2).

Ariani, K. R., \& Bawono, A. D. (2018). Pengaruh Ukuran dan Umur Perusahaan Terhadap Audit Report Lag Dengan Profitabilitas dan Solvabilitas Sebagai Variabel Moderating. Riset Akuntansi dan Keuangan Indonesia 3(2). 
Arifuddin, Hanafi, K., \& Usman, A. (2017). Company Size, Profitability, and Auditor Opinion Influence to Audit Report Lag on Registered Manufacturing Company in Indonesia Stock Exchange. International Journal of Applied Business and Economic Research, Volume 15, Number 19.

Ayuningtyas, D. (2019), Perhatian!! 24 Emiten Ini Kena Sanksi BEI Kenapa? Retrieved from cnbcindonesia.com: https://www.cnbcindonesia.com/market/20190509090006-1771388/perhatian-24-emiten-ini-kena-sanksi-bei-kenapa

Butarbutar, R. S., \& Hadiprajitno, P. B. (2017). Analisis Faktor-Faktor yang Berpengaruh Terhadap Audit Report Lag (Studi Empiris Pada Perusahaan Manufaktur Yang Terdaftar Dibursa Efek Indonesia Tahun 2012-2015). Diponegoro Journal of Accounting.

Dewi, I. C., \& Hadiprajitno, P. (2017). Pengaruh Audit Tenure dan Kantor Akuntan Publik (KAP) Spesialisasi manufaktur Terhadap Audit Report Lag (ARL). Diponegoro Journal of Accounting.

Faisal, M., \& Hadiprajitno, P. (2015). Pengaruh Mekanisme Good Corporate Governance Terhadap Audit Report Lag. Diponegoro Journal Of Accounting.

Ghozali, I. (2016). Aplikasi Analisis Multivariate dengan Program IBM SPSS 23. Semarang: UNDIP.

Habib, A., Bhuiyan, M. B. U., Huang, H. J., \& Miah, M. S. (2018). Determinants of Audit Report Lag. International Journal of Auditing. Vol 23, Issue 1.

Hayes, R., Wallage, P., \& Gortemaker, H. (2017). Prinsip-prinsip Pengauditan International Standards on Auditing. Jakarta: Salemba Empat.

Otoritas Jasa Keuangan. (2016). Peraturan Otoritas Jasa Keuangan Nomor 29/ POJK.04/2016 tentang Laporan Tahunan Emiten Atau Perusahaan Publik. Jakarta: Kementrian Hukum dan Hak Asasi Manusia.

Kusumah, R. W., \& Manurung, D. T. (2017). Pentingkah Good Corporate Governance Bagi Audit Report Lag? Jurnal Akuntansi Multiparadigma.

Mahendra, A. N., \& Widhiyani, N. S. (2017). Pengaruh GCG, Opini Auditor dan Internal Auditor Terhadap Audit Delay Pada Perusahaan Telekomunikasi di BEI. E-Jurnal Akuntansi Universitas Udayana.

Sari, R. R., \& Ghozali, I. (2014). Faktor-Faktor Pengaruh Audit Report Lag. Diponegoro Journal of Accounting.

Vitarini, T., \& Siswanto, E. (2017). Sinyal yang Ditimbulkan oleh Informasi Arus Kas, Laba dan Nilai Tambah Pasar dalam Mendongkrak Harga Saham Perusahaan Consumer Goods di Indonesia. Ekonomi Bisnis.

Wardhani, A. P., \& Raharja, S. (2013). Analisis Pengaruh Corporate Governance Terhadap Audit Report Lag. Diponegoro Journal of Accounting.

www.bapepam.go.id diakses bulan November 2019. 
www.idfinancial.com diakses pada bulan Januari 2020.

www.idx.co.od diakses pada bulan Januari 2020.

www.sahamok.com diakses pada bulan November 2019. 